\title{
Determination of Screw Withdrawal Resistance of Some Heat-Treated Wood Species
}

\section{Određivanje otpora toplinski obrađenog drva izvlačenju vijaka}

\author{
Original scientific paper • Izvorni znanstveni rad \\ Received-prispjelo: 1. 6. 2016. \\ Accepted-prihvaćeno: 15. 11. 2016. \\ UDK: $630 * 824.23$ \\ doi:10.5552/drind.2017.1630
}

\begin{abstract}
In this study, the screw withdrawal resistance of heat-treated hornbeam (Carpinus betulus L.), black pine (Pinus nigra Arnold) and Uludağ fir (Abies bornmuellerinana Mattf.) was determined according to the ASTM D 1761 standard. For this purpose, wood materials were heat treated at 150, 170, 190 and $210{ }^{\circ} \mathrm{C}$ for $3 \mathrm{~h}$. After the heat treatment, the screw withdrawal resistance of the wood was determined in radial, tangential and transverse directions. As a result, the screw withdrawal resistance values decreased with increasing heat treatment temperature and the lowest resistance was obtained in the wood heat-treated at $210^{\circ} \mathrm{C}$. In terms of wood species, the highest screw withdrawal resistance was found in hornbeam (Carpinus betulus L.), while the lowest value was observed in black pine (Pinus nigra Arnold). Additionally, in terms of the cross-sectional direction, the highest screw withdrawal resistance was determined in the tangential direction, while the lowest resistance value was observed in the transverse direction.
\end{abstract}

Key words: heat treatment, black pine, hornbeam, Uludă̆ fir, screw withdrawal resistance

\begin{abstract}
SAŽETAK • Ovim je istraživanjem određena veličina otpora drva izvlačenju vijaka na uzorcima od toplinski obrađenog drva graba (Carpinus betulus L.), crnog bora (Pinus nigra Arnold) i turske jele (Abies bornmuelleriana Mattf.), u skladu s normom ASTM D 1761. Za tu svrhu drvni su materijali toplinski obrađeni pri 150, 170, 190 $i 210{ }^{\circ} \mathrm{C}$ tijekom tri sata. Nakon toplinske obrade određen je otpor drva izvlačenju vijaka na radijalnome, tangencijalnome i poprečnom presjeku drva. Rezultati istraživanja pokazali su da se vrijednosti otpora drva izvlačenju vijaka smanjuju s povećanjem temperature njegove toplinske obrade, a najmanji otpor zabilježen je za drvo toplinski obrađeno pri $210^{\circ} \mathrm{C}$. S obzirom na vrstu drva, najveći otpor izvlačenju vijaka izmjeren je na uzorcima od drva graba (Carpinus betulus L.), a najmanja je vrijednost izmjerena za uzorke od drva crnog bora (Pinus Nigra Arnold). S obzirom na presjek drva, najveći je otpor izvlačenju vijaka izmjeren na tangencijalnome, a najmanji na poprečnom presjeku drva.
\end{abstract}

Ključne riječi: toplinska obrada, crni bor, grab, turska jela, otpor izvlačenju vijaka

\footnotetext{
Author is assistant professor at Necmettin Erbakan University, Faculty of Fine Arts, Department of Interior Architecture and Environmental Design, Konya, Turkey. ${ }^{2}$ Author is assistant professor at Gumushane University, Gumushane Vocational High School, Department of Design, Gumushane, Turkey. ${ }^{3}$ Author is professor at Gazi University, Faculty of Technology, Department of Wood Products Industrial Engineering, Ankara, Turkey. ${ }^{4}$ Author is assistant professor at Cankırı Karatekin University, Technical and Business College, Çankırı, Turkey.

Autor je docent Sveučilišta Necmettin Erbakan, Fakultet likovnih umjetnosti, Odjel za uređenje interijera i dizajn okoliša, Konya, Turska.

${ }^{2}$ Autor je docent Sveučilišta Gumushane, Strukovna visoka škola, Odjel za dizajn, Gumushane, Turska. ${ }^{3}$ Autor je profesor Sveučilišta Gazi, Tehnološki fakultet, Odjel za industrijski inženjering drvnih proizvoda, Ankara, Turska. ${ }^{4}$ Autor je docent Sveučilišta Cankırı Karatekin, Tehnički i poslovni koledž, Çankırı, Turska.
} 


\section{INTRODUCTION}

\section{UVOD}

In recent years, as a result of increasing environmental consciousness, consumers have started to question the possible toxic effects of wood-modification applications using chemicals on the environment. This phenomenon has paved the way for developing alternative modification methods to preserve wood material - an eco-friendly and sustainable source. Heat treatment using adjustable treatment parameters is one of them i.e. an alternative modification method to chemical use that increases the wood dimensional stability and enhances its resistance against biological attack by reducing hygroscopicity and generating molecules toxic to fungi (Hill, 2006; Wang and Cooper, 2005). In this method, wood materials are heated in an oxygenfree environment at a temperature between 150 and $250^{\circ} \mathrm{C}$. The heat treatment processes have been known for a very long time and they include several different methods. The main differences between the heat treatment processes are to be seen in the process conditions (process steps, oxygen or nitrogen, steaming, wet or dry process, the use of oils, steering schedules, etc.) (Militz, 2002). The heat-treated wood materials have very broad application areas ranging from outdoor uses such as sidings, doors, windows and garden furniture to indoor uses such as floors, paneling, baths and saunas (Viitaniemi, 2000). The dimensional stability and biological resistance of heat-treated wood materials increases, while their mechanical resistance decreases, which makes their use in load-bearing systems limited (Bekhta and Niemz, 2003; Esteves and Pereira, 2009; Korkut, 2008; Yildiz 2002; Korkut and Guller, 2008). The color of wood changes, and changes in mechanical properties have also been observed as a result of the heat treatment. Changes observed in physical and mechanical properties of heat-treated wood materials influence their performance in applications either positively or negatively (Ayan and Ciritcioğlu, 2012).

Some factors of the wood material, especially species and thickness, have some effects on the rigidity and durability of the wood structure elements. The screws are commonly used as joint components of the wood construction in engineered wood structures and, since each wood species has its own properties, they also have different screw withdrawal resistance. Therefore, the determination of this withdrawal resistance for some wood species is important for wood applications (Aytekin, 2008). The durability and stability of each structure depends on the performance of the fasteners. The screws are one of the fasteners widely used in the woodworking and furniture industries. Therefore, the knowledge regarding the withdrawal resistance of screws for wooden building elements will provide useful information about the durability and stability of the whole system (Celebi and Kilic, 2006). The number of screws, pilot-hole diameters, screw depth and material cross-sections should be taken into consideration in wood or wooden material applications (Faherty and Williamson, 1998; Koch, 1972).
Poncsák et al. (2006), investigated the effect of high heat treatment temperature on screw withdrawal resistance of birch (Betula papyrifera). They indicated that some decreases in screw withdrawal resistance were observed as a result of high temperature. Kocaefe et al. (2008) investigated the effects of heat treatment on technological properties of jack pine (Pinus banksiana Lamb.) and aspen (Populus tremuloides Michx.). They stated that screw withdrawal resistance of heat-treated jack pine decreased, but this decrease was not significantly different from the control samples. Also, screw withdrawal resistance of heat-treated aspen was found to be relatively higher than that of untreated samples. Kariz et al. (2013) determined the screw withdrawal resistance in the radial and tangential direction on the heat-treated spruce (Picea abies Karst.) at 150, 170, 190, 210, and $230{ }^{\circ} \mathrm{C}$. The results indicated that there was a greater decrease in screw withdrawal resistance for heat treatment conditions, and they concluded that the size of deformation around the screw increased at higher temperatures based on the analysis of the images of the deformed surface left by the screws.

The amount of use and application areas of heattreated wooden materials has substantially increased. Most of the joints use screws. Thus, the determination of screw withdrawal resistance of heat-treated wood materials is of importance in terms of high efficiency and strength of the structure. The aim of this study is to determine screw withdrawal resistance of the samples produced from heat-treated hornbeam (Carpinus betulus L.), black pine (Pinus nigra Arnold) and Uludag fir (Abies bornmuelleriana Mattf.).

\section{MATERIALS AND METHODS \\ 2. MATERIJALI I METODE}

Hornbeam (Carpinus betulus L.), black pine ( $P$ inus nigra Arnold), and Uludağ fir (Abies bornmuellerinana Mattf.) were selected randomly from timber merchants as test materials because of their wide use in industry. Special emphasis was given for the selection of wood materials; non-deficient, proper, knotless, and normally grown (without zone line, reaction wood, decay, or damage caused by wood decay fungi) materials were selected. The samples were cut into in the dimensions of 60 (thickness) x 60 (width) x 780 (length) $\mathrm{mm}$ before the heat treatment, including radial, tangential and transverse cross-sections. The wood samples were conditioned to $12 \%$ moisture contents (MC) in a conditioning device at $20{ }^{\circ} \mathrm{C}( \pm 2)$ and $65 \%( \pm 5)$ relative humidity for two months before being planed and cut into small specimens.

\subsection{Preparation of test samples and their heat treatment}

\subsection{Priprema uzoraka i njihova toplinska obrada}

The small clear specimens were cut into 50 x 50 x $150 \mathrm{~mm}$ pieces for withdrawal tests before the heat treatment. Then they were completely dried at a temperature of $103 \pm 2{ }^{\circ} \mathrm{C}$ until they had a constant weight. Completely dried samples were taken from the drying 


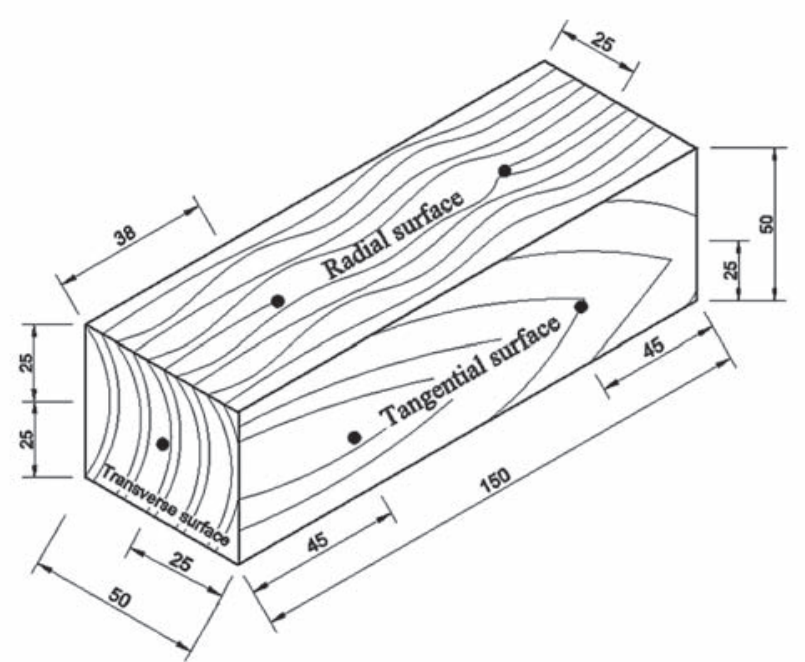

Figure 1 Test samples used for screw withdrawal resistance and screw positions

Slika 1. Uzorak drva za određivanje otpora izvlačenju vijaka s prikazom njihova položaja

oven and weighed on an electronic balance to the precision of $0.01 \mathrm{~g}$. The heat treatment applications were conducted in a temperature controlled small heating unit. 4 different temperatures (150, 170, 190 and 210 ${ }^{\circ} \mathrm{C}$ and for $3 \mathrm{~h}$.) were applied to specimens under atmospheric pressure and in the presence of air. After heat treatment, treated and control samples were conditioned to $12 \%$ moisture contents $(M C)$ in a conditioning chamber at $20{ }^{\circ} \mathrm{C}( \pm 2)$ and $65 \%( \pm 5)$ relative humidity to reach equilibrium moisture content. The test samples used for screw withdrawal resistance tests, and screw positions are shown in Fig. 1. (ASTM D 1761, 2000).

The screws were driven into pilot holes, $70 \%$ of the core diameter of the screw and $15 \mathrm{~mm}$ depth, drilled on the face of the specimens. Six wood screws ( 4 x 50) for each sample were used for the withdrawal tests (Fig. 1). All of the screws were embedded $32 \pm 0.5 \mathrm{~mm}$ deep in the surface of the test samples. The withdrawal resistance was determined in the radial, tangential, and transverse directions. Screw-withdrawal resistance tests were carried out using the universal test equipment, in accordance with the ASTM D 1761 standard. During the tests, the loading rate was $2 \mathrm{~mm} / \mathrm{min}$ for all tests. Ten test samples for the withdrawal resistance tests were prepared for each group. The screw-withdrawal resistance values were calculated according to Equation 1.

Where:

$$
\sigma_{\mathrm{s}}=\frac{F_{\max }}{2 \cdot \pi \cdot r \cdot h}
$$

$\sigma_{\mathrm{s}}-$ screw-withdrawal resistance, $\mathrm{N} / \mathrm{mm}^{2}$

$F_{\text {max }}$ - maximum load, N

$2 \cdot \pi \cdot r \cdot h$ - surface area of the screw exposed to friction, $\mathrm{mm}^{2}$.

Weight loss $(W L)$ after heat treatment was calculated according to Equation 2.

$$
W L=\frac{M 0-M 1}{M 0} \cdot 100
$$

Where $W L$ is weight loss $(\%), M_{0}$ is the initial oven dried mass of the wood sample before the treat- ment and $M_{1}$ is the oven dried mass of the same sample after the treatment.

\subsection{Analysis of data}

MSTATC statistical software package was used for the statistical evaluation of the results and to show the effects of the type of wood material and the temperature of heat treatment on screw-withdrawal resistance. The interactions between these factors were determined using multivariate analysis of variance (MANOVA). The comparisons were made using the critical values obtained from the LSD (least significant difference) test, and the factors causing the differences were identified.

\section{RESULTS AND DISCUSSION 3. REZULTATI I RASPRAVA}

The average values and standard deviations of weight loss $(W L)$, density, and equilibrium moisture content $(E M C)$ of heat-treated and control wood are given in Table 1.

As shown in Table 1, the weight loss values generally exhibited a decrease with increasing heat treatment temperature. The highest weight loss values were obtained from heat-treated at $210{ }^{\circ} \mathrm{C}$ for black pine, hornbeam, and Uludağ fir $(4.91 \%, 6.98 \%$, and $3.72 \%$, respectively). The weight loss of the wood is one of the most important features in heat treatment and is commonly referred to as an indication of the quality. The weight loss depends on the wood species, heating medium, temperature, and treatment time (Esteves and Pereira, 2009). Alén et al. (2002) studied the weight loss of heat-treated spruce at temperatures between $180{ }^{\circ} \mathrm{C}$ and $225^{\circ} \mathrm{C}$ during 4 to $8 \mathrm{~h}$ and found $1.5 \%$ weight loss at $180{ }^{\circ} \mathrm{C}$ for $4 \mathrm{~h}$ and $12.5 \%$ at $225^{\circ} \mathrm{C}$ for 6h. Similar results were also found in previous studies (Yildiz, 2002; Ozcifci et al. 2009; Malek et al. 2013). The weight loss of the heat-treated wood samples is due to the degradation of the wood polymers depending on the heat treatment temperature and treatment time, the hemicelluloses generally being the most thermally-sensitive wood components (Poncsák et al. 2006; Yildiz et al. 2006).

As shown in Table 1, the oven-dried density values decrease with increasing heat treatment temperature for three wood species. The heat-treated wood samples at a temperature of $210{ }^{\circ} \mathrm{C}$ gave the lowest air-dried density values when compared with other conditions studied. While the maximum effect of the heat treatment was recorded at $210{ }^{\circ} \mathrm{C}$, the minimum effect was recorded at $150^{\circ} \mathrm{C}$. Gunduz et al. (2009) studied the effects of heat treatment on the density properties of hornbeam. Their research indicated that the minimum density loss of $0.76 \%$ occurred at treatment conditions of $170{ }^{\circ} \mathrm{C}$ for $4 \mathrm{~h}$, whereas the maximum density loss of $16.12 \%$ occurred at treatment conditions of $210^{\circ} \mathrm{C}$ for $12 \mathrm{~h}$. Another study showed a similar reduction of air-dried density for heat-treated Anatolian black pine wood (Akyildiz et al. 2009). 
Table 1 Average values of WL, density and EMC of heat-treated wood

Tablica 1. Prosječne vrijednosti gubitka mase, gustoće i ravnotežnog sadržaja vode toplinski obrađenog drva

\begin{tabular}{|c|c|c|c|c|c|c|c|c|c|c|}
\hline \multirow{2}{*}{$\begin{array}{l}\text { Wood } \\
\text { species } \\
\text { Vrsta drva }\end{array}$} & \multirow{2}{*}{$\begin{array}{l}\text { Heat treatment } \\
\text { temperature } \\
\text { Temperatura } \\
\text { toplinske obrade }\end{array}$} & \multicolumn{3}{|c|}{$\begin{array}{c}W L \\
\%\end{array}$} & \multicolumn{3}{|c|}{$\begin{array}{l}\text { Density } \\
\mathrm{g} / \mathrm{cm}^{3}\end{array}$} & \multicolumn{3}{|c|}{$\begin{array}{c}\text { EMC } \\
\%\end{array}$} \\
\hline & & $X$ & $s d$ & $N$ & $X$ & $s d$ & $N$ & $X$ & $s d$ & $N$ \\
\hline \multirow{5}{*}{$\begin{array}{l}\text { Black pine } \\
\text { crni bor }\end{array}$} & Control & - & - & - & 0.511 & 0.016 & 10 & 13.35 & 0.788 & 10 \\
\hline & $150^{\circ} \mathrm{C}$ & 1.12 & 0.106 & 10 & 0.506 & 0.012 & 10 & 10.41 & 0.612 & 10 \\
\hline & $170^{\circ} \mathrm{C}$ & 2.11 & 0.127 & 10 & 0.501 & 0.018 & 10 & 9.78 & 0.422 & 10 \\
\hline & $190^{\circ} \mathrm{C}$ & 3.18 & 0.143 & 10 & 0.494 & 0.017 & 10 & 8.12 & 0.476 & 10 \\
\hline & $210^{\circ} \mathrm{C}$ & 4.91 & 0.175 & 10 & 0.484 & 0.018 & 10 & 6.89 & 0.246 & 10 \\
\hline \multirow{5}{*}{$\begin{array}{l}\text { Hornbeam } \\
\text { grab }\end{array}$} & Control & - & - & - & 0.653 & 0.014 & 10 & 11.83 & 0.433 & 10 \\
\hline & $150^{\circ} \mathrm{C}$ & 1.22 & 0.105 & 10 & 0.646 & 0.015 & 10 & 9.17 & 0.274 & 10 \\
\hline & $170^{\circ} \mathrm{C}$ & 2.34 & 0.191 & 10 & 0.634 & 0.011 & 10 & 8.44 & 0.251 & 10 \\
\hline & $190^{\circ} \mathrm{C}$ & 3.93 & 0.397 & 10 & 0.623 & 0.014 & 10 & 7.23 & 0.211 & 10 \\
\hline & $210^{\circ} \mathrm{C}$ & 6.98 & 0.434 & 10 & 0.601 & 0.015 & 10 & 5.11 & 0.212 & 10 \\
\hline \multirow{5}{*}{$\begin{array}{l}\text { Uludağ fir } \\
\text { turska jela }\end{array}$} & Control & - & - & - & 0.426 & 0.011 & 10 & 12.42 & 0.363 & 10 \\
\hline & $150^{\circ} \mathrm{C}$ & 0.91 & 0.111 & 10 & 0.422 & 0.012 & 10 & 10.16 & 0.319 & 10 \\
\hline & $170^{\circ} \mathrm{C}$ & 1.76 & 0.222 & 10 & 0.417 & 0.011 & 10 & 9.83 & 0.315 & 10 \\
\hline & $190^{\circ} \mathrm{C}$ & 2.79 & 0.131 & 10 & 0.411 & 0.013 & 10 & 7.67 & 0.298 & 10 \\
\hline & $210^{\circ} \mathrm{C}$ & 3.72 & 0.135 & 10 & 0.407 & 0.012 & 10 & 6.26 & 0.191 & 10 \\
\hline
\end{tabular}

WL - weight loss / gubitak mase; EMC - equilibrium moisture content / ravnotežni sadržaj vode; X - average value / prosječna vrijednost; $s d$ - standard deviation / standardna devijacija; $N$ - the number of test samples / broj uzoraka

Also, Korkut and Bektaş (2008) conducted research on heat-treated Uludağ fir (Abies bornmuellerinana Mattf.) and Scots pine (Pinus sylvestris L.) and confirmed that the air-dried density values decreased. The conversion of hemicelluloses into volatile products and evaporation of some extractive substances play an important role in decreasing density values after heat treatment (Esteves et al., 2008).

Table 1 shows the results of equilibrium moisture content (EMC) of black pine, hornbeam, and Uludağ fir treated at four different temperatures $(150,170,190$, and $210^{\circ} \mathrm{C}$ ) for 3 hours. Treatment at $150{ }^{\circ} \mathrm{C}$ resulted in the lowest values for the EMC. The wood samples heat treated at a temperature of $210^{\circ} \mathrm{C}$ have the lowest
EMC value of $5.11 \%$ for hornbeam wood when compared with other species studied. On the other hand, the highest EMC value was $10.41 \%$ for black pine wood at a temperature of $150{ }^{\circ} \mathrm{C}$. In addition, a lower effect of heat treatment was observed when the samples were treated at $150{ }^{\circ} \mathrm{C}$. Accessibility of hydroxyl groups to water molecules becomes difficult due to the increasing cellulose crystallinity, as a result of the degradation of amorphous cellulose. This phenomenon causes a decrease in the EMC value (Bhuiyan and Hirai, 2005; Boonstra and Tjeerdsma, 2006). The hydrolysis of hemicellulose into less hygroscopic furfural polymers causes a decrease in the EMC value (Boonstra, 2008). The results of the multivariate analysis of the screw

Table 2 Results of the Analysis of Variance

Tablica 2. Rezultati analize varijance

\begin{tabular}{|c|c|c|c|c|c|c|}
\hline $\begin{array}{l}\text { Direction } \\
\text { Smjer }\end{array}$ & Factor / Činitelj & $\begin{array}{l}\text { Degrees of } \\
\text { Freedom } \\
\text { Stupanj } \\
\text { slobode }\end{array}$ & $\begin{array}{l}\text { Sum of } \\
\text { Squares } \\
\text { Zbroj } \\
\text { kvadrata }\end{array}$ & $\begin{array}{c}\text { Mean of Squares } \\
\text { Srednja vrijednost } \\
\text { kvadrata }\end{array}$ & $\begin{array}{c}\text { F value } \\
\text { Vrijednost } F\end{array}$ & $\begin{array}{l}\text { Level of significance } \\
\text { Razina signifikantnosti } \\
\quad(P \leq 0.05)\end{array}$ \\
\hline \multirow{5}{*}{$\begin{array}{c}\text { Radial } \\
\text { radijalni }\end{array}$} & Factor A & 2 & 3104.977 & 1552.488 & 45026.8203 & 0.0000 \\
\hline & Factor B & 4 & 410.528 & 102.632 & 2976.6372 & 0.0000 \\
\hline & Interaction $\mathrm{A} * \mathrm{~B}$ & 8 & 404.066 & 50.508 & 1464.8908 & 0.0000 \\
\hline & Error & 135 & 4.655 & 0.034 & & \\
\hline & Total & 149 & 3924.226 & & & \\
\hline \multirow{5}{*}{$\begin{array}{c}\text { Tangential } \\
\text { tangencijalni }\end{array}$} & Factor A & 2 & 2265.917 & 1132.959 & 42944.0058 & 0.0000 \\
\hline & Factor B & 4 & 444.288 & 111.072 & 4210.1104 & 0.0000 \\
\hline & Interaction $\mathrm{A} * \mathrm{~B}$ & 8 & 209.299 & 26.162 & 991.6657 & 0.0000 \\
\hline & Error & 135 & 3.562 & 0.026 & & \\
\hline & Total & 149 & 2923.066 & & & \\
\hline \multirow{5}{*}{$\begin{array}{l}\text { Transverse } \\
\text { poprečni }\end{array}$} & Factor A & 2 & 2810.115 & 1009.057 & 34193.6653 & 0.0000 \\
\hline & Factor B & 4 & 201.161 & 50.290 & 1704.1708 & 0.0000 \\
\hline & Interaction $\mathrm{A} * \mathrm{~B}$ & 8 & 78.031 & 9.754 & 330.5276 & 0.0000 \\
\hline & Error & 135 & 3.984 & 0.030 & & \\
\hline & Total & 149 & 2301.291 & & & \\
\hline
\end{tabular}

Factor A - wood species / vrsta drva; Factor B - heat treatment temperature / temperatura toplinske obrade 
Table 3 Comparative test results for the effect of wood species for radial, tangential, and transverse directions $\left(\mathrm{N} / \mathrm{mm}^{2}\right)$ Tablica 3. Rezultati usporednog testa za mjerenje utjecaja vrste drva pri radijalnome, tangencijalnome i poprečnom presjeku drva

\begin{tabular}{|l|c|c|c|c|c|c|}
\hline \multirow{2}{*}{$\begin{array}{l}\text { Wood species } \\
\text { Vrsta drva }\end{array}$} & \multicolumn{2}{|c|}{$\begin{array}{c}\text { Radial* } \\
\text { Radijalni }\end{array}$} & \multicolumn{2}{c|}{$\begin{array}{c}\text { Tangential** } \\
\text { Tangencijalni }\end{array}$} & \multicolumn{2}{c|}{$\begin{array}{c}\text { Transverse*** } \\
\text { Poprečni }\end{array}$} \\
\cline { 2 - 7 } & $X$ & HG & $X$ & HG & $X$ & HG \\
\hline Black pine / crni bor & 16.26 & C & 16.78 & C & 14.92 & C \\
\hline Hornbeam / grab & 25.95 & A & 25.31 & A & 22.78 & A \\
\hline Uludağ fir / turska jela & 16.34 & B & 17.37 & B & 15.08 & B \\
\hline
\end{tabular}

LSD: *0.07287, **0.06372, ***0.06845; X - average value / prosječna vrijednost; HG: homogeneous group / homogena skupina. Different letters in HG column refer to significant differences among wood species at 0.05 confidence level. / Različita slova u stupcu označenome s HG potvrđuju postojanje signifikantne razlike između vrsta drva pri razini signifikantnosti 0,05.

withdrawal resistance for the heat-treated and untreated (control) wood materials for the radial, tangential, and transverse directions are shown in Table 2.

The results of the analysis of variance indicated that the effects of the wood species, heat-treatment temperature and their interactions were found to be statistically significant $(P \leq 0.05)$ for the radial, tangential, and transverse directions. The comparative LSD test results for different wood species are given in Table 3 .

As shown in Table 3, the highest screw withdrawal resistance was achieved in the hornbeam (Carpinus betulus L.) wood, followed by Uludağ fir (Abies bornmuellerinana Mattf.) and black pine (Pinus nigra Arnold), respectively. The highest resistance values for black pine and Uludağ fir were found in the tangential direction, while the lowest value was observed in the transverse surface. This may be caused by the arrangement of wood cells and fiber angle orientations. The screw withdrawal resistance of the radial direction of the hornbeam wood was found slightly higher than that of its tangential direction. Regarding wood species, the maximum screw withdrawal resistance was determined in hornbeam wood. This may be due to its high density. The density of hornbeam wood was the highest among the three species of the present study (Table 1). In fact, the highest screw withdrawal resistance was also found in hornbeam wood, in radial, tangential, and transverse directions. It may, therefore, be concluded that density and species may have a decisive importance for screw withdrawal resistance. In literature,
Bal et al. (2015) stated that there was a strong relationship between the screw withdrawal resistance and the density of wood and that the screw holding resistance of the higher density beech plywood was higher than that of other lower density plywood panels. Akyildiz and Malkoçoğlu (2001) reported that the screw withdrawal resistance increased with increasing density of wood. The comparative LSD test results for the heat treatment temperatures are given in Table 4 .

As shown in Table 4, the highest screw withdrawal resistance in radial, tangential, and transverse directions was found in the heat treated samples at $150^{\circ} \mathrm{C}$, while the lowest value was found in the heat treated samples at $210^{\circ} \mathrm{C}$. Table 4 clearly shows that increasing heat treatment temperature reduces the screw withdrawal resistance. The reason for screw withdrawal resistance decreasing after heat treatment may be caused by the mass losses as a result of the degradation of hemicelluloses and by degradation of wood (Viitanen et al. 1994; Fengel and Wegener, 1989). Also, the density plays an important role in the mechanical strength of wood. Gašparík et al. (2015) investigated the effect of the heat treatment on screw withdrawal resistance of wood. They reported that screw withdrawal resistance of the heat-treated wood decreased depending on lower density and moisture content of wood, which resulted from heat treatment. The results of the LSD test for a comprehensive comparison of the effects of wood species, surface section, and heat treatment temperature on the screw withdrawal resistance are shown in Table 5.

Table 4 Comparative test results for the effect of heat treatment temperatures for radial, tangential, and transverse directions $\left(\mathrm{N} / \mathrm{mm}^{2}\right)$

Tablica 4. Rezultati usporednog testa za mjerenje utjecaja temperature toplinske obrade pri radijalnome, tangencijalnome i poprečnom presjeku drva

\begin{tabular}{|l|c|c|c|c|c|c|}
\hline $\begin{array}{l}\text { Heat treatment } \\
\text { temperature } \\
\text { Temperatura toplinske } \\
\text { obrade }\end{array}$ & \multicolumn{2}{|c|}{$\begin{array}{c}\text { Radial* } \\
\text { Radijalni }\end{array}$} & \multicolumn{2}{c|}{$\begin{array}{c}\text { Tangential } \\
\text { Tangencijalni }\end{array}$} & \multicolumn{2}{c|}{$\begin{array}{c}\text { Transverse*** } \\
\text { Poprečni }\end{array}$} \\
\cline { 2 - 7 } & $X$ & HG & $X$ & HG & $X$ & HG \\
\hline Control & 21.16 & $\mathrm{~A}$ & 21.29 & $\mathrm{~A}$ & 18.57 & $\mathrm{~B}$ \\
\hline $150^{\circ} \mathrm{C}$ & 20.94 & $\mathrm{~B}$ & 21.40 & $\mathrm{~B}$ & 18.73 & $\mathrm{~A}$ \\
\hline $170^{\circ} \mathrm{C}$ & 20.36 & $\mathrm{C}$ & 20.29 & $\mathrm{C}$ & 17.98 & $\mathrm{C}$ \\
\hline $190^{\circ} \mathrm{C}$ & 18.09 & $\mathrm{D}$ & 18.82 & $\mathrm{D}$ & 17.10 & $\mathrm{D}$ \\
\hline $210^{\circ} \mathrm{C}$ & 17.03 & $\mathrm{E}$ & 17.00 & $\mathrm{E}$ & 15.57 & $\mathrm{E}$ \\
\hline
\end{tabular}

LSD: $* 0.09438, * * 0.08227, * * * 0.08837 ; X$ - average value / prosječna vrijednost; HG: homogeneous group / homogena skupina. Different letters in HG column refer to significant differences among wood species at 0.05 confidence level. / Različita slova u stupcu označenome s HG potvrđuju postojanje signifikantne razlike između vrsta drva pri razini signifikantnosti 0,05. 
Table 5 Comprehensive comparison analysis of wood species, direction section, and heat treatment temperature on screw withdrawal resistance $\left(\mathrm{N} / \mathrm{mm}^{2}\right)$

Tablica 5. Cjelovita analiza utjecaja vrste drva, presjeka drva i temperature toplinske obrade drva na otpor izvlačenju vijaka $\left(\mathrm{N} / \mathrm{mm}^{2}\right)$

\begin{tabular}{|c|c|c|c|c|c|c|c|}
\hline \multirow{2}{*}{$\begin{array}{l}\text { Wood species } \\
\text { Vrsta drva }\end{array}$} & \multirow{2}{*}{$\begin{array}{c}\text { Heat treatment } \\
\text { temperature } \\
\text { Temperatura toplinske obrade }\end{array}$} & \multicolumn{2}{|c|}{$\begin{array}{l}\text { Radial* } \\
\text { Radijalni }\end{array}$} & \multicolumn{2}{|c|}{$\begin{array}{l}\text { Tangential** } \\
\text { Tangencijalni }\end{array}$} & \multicolumn{2}{|c|}{$\begin{array}{c}\text { Transverse**** } \\
\text { Poprečni }\end{array}$} \\
\hline & & $X$ & HG & $X$ & $\mathrm{HG}$ & $X$ & $\mathrm{HG}$ \\
\hline \multirow{5}{*}{$\begin{array}{l}\text { Black pine } \\
\text { crni bor }\end{array}$} & Control & 17.50 & $\mathrm{~F}$ & 18.46 & $\mathrm{~F}$ & 16.21 & $\mathrm{G}$ \\
\hline & $150^{\circ} \mathrm{C}$ & 17.28 & $\mathrm{G}$ & 18.23 & G & 16.37 & $\mathrm{~F}$ \\
\hline & $170^{\circ} \mathrm{C}$ & 16.45 & $\mathrm{I}$ & 16.87 & $\mathrm{~K}$ & 15.43 & $\mathrm{H}$ \\
\hline & $190^{\circ} \mathrm{C}$ & 15.17 & $\mathrm{~L}$ & 16.12 & $\mathrm{M}$ & 14.01 & $\mathrm{M}$ \\
\hline & $210^{\circ} \mathrm{C}$ & 14.89 & $\mathrm{M}$ & 14.24 & $\mathrm{~N}$ & 12.58 & $\mathrm{~N}$ \\
\hline \multirow{5}{*}{$\begin{array}{l}\text { Hornbeam } \\
\text { grab }\end{array}$} & Control & 29.98 & $\mathrm{~A}$ & 28.74 & $\mathrm{~A}$ & 24.16 & $\mathrm{~B}$ \\
\hline & $150^{\circ} \mathrm{C}$ & 29.23 & $\mathrm{~B}$ & 28.35 & $\mathrm{~B}$ & 24.59 & A \\
\hline & $170^{\circ} \mathrm{C}$ & 27.88 & $\mathrm{C}$ & 26.12 & $\mathrm{C}$ & 23.44 & $\mathrm{C}$ \\
\hline & $190^{\circ} \mathrm{C}$ & 22.19 & $\mathrm{D}$ & 23.12 & $\mathrm{D}$ & 22.32 & $\mathrm{D}$ \\
\hline & $210^{\circ} \mathrm{C}$ & 20.48 & $E$ & 20.21 & $E$ & 19.38 & $\mathrm{E}$ \\
\hline \multirow{5}{*}{$\begin{array}{l}\text { Uludağ fir } \\
\text { turska jela }\end{array}$} & Control & 16.01 & $\mathrm{~J}$ & 17.57 & $\mathrm{I}$ & 15.35 & $\mathrm{HI}$ \\
\hline & $150^{\circ} \mathrm{C}$ & 16.32 & $\mathrm{I}$ & 17.63 & $\mathrm{I}$ & 15.22 & $\mathrm{IJ}$ \\
\hline & $170^{\circ} \mathrm{C}$ & 16.76 & $\mathrm{H}$ & 17.89 & $\mathrm{H}$ & 15.07 & JK \\
\hline & $190^{\circ} \mathrm{C}$ & 16.91 & $\mathrm{H}$ & 17.23 & $\mathrm{~J}$ & 14.98 & $\mathrm{~K}$ \\
\hline & $210^{\circ} \mathrm{C}$ & 15.72 & $\mathrm{~K}$ & 16.55 & $\mathrm{~L}$ & 14.77 & $\mathrm{~L}$ \\
\hline
\end{tabular}

*LSD: 0.1629,**:0.1425,***: 0.1531, X- average value / prosječna vrijednost; HG: homogeneous group / homogena skupina. Different letters in HG column refer to significant differences among wood species at 0.05 confidence level. / Različita slova u stupcu označenome s HG potvrđuju postojanje signifikantne razlike između vrsta drva pri razini signifikantnosti 0,05.

The screw withdrawal resistance of wood species decreased with increasing temperature. Generally, in terms of direction, the lowest screw withdrawal resistance was found in transverse direction. The reason lies in the fact that the screws drawn perpendicularly in the surfaces were also in the direction of grain configuration of test samples. Therefore, it was concluded that it would be useful to take into consideration the effects of grain direction on withdrawal resistance.

Hornbeam was the most affected by heat treatment, while Uludağ fir (Abies bornmuellerinana Mattf.) was the least affected. In other words, screw withdrawal resistance in hornbeam decreased much more compared to other wood species. The reason for this was probably caused by degradation of hemicelluloses. The chemical composition of wood varies from species to species. In general, hardwoods contain more hemicellulose than softwoods (Baeza and Freer 2001). The degradation of the hemicelluloses starts to take place at a relatively low temperature (between 160 and $\left.260{ }^{\circ} \mathrm{C}\right)$. Also, the degradation of the hemicelluloses increases with heat treatment temperature and treatment time (Poncsák et al. 2006, Yildiz et al. 2011). The softwoods are more thermally stable than hardwoods, which is the result of their hemicellulose content and compositional differences (Fengel and Wegener, 1989). Perçin (2015) studied screw withdrawal resistance of laminated samples produced from heat-treated oak (Quercus petraea Liebl.) at $140,170,200$ and $230^{\circ} \mathrm{C}$ for $2 \mathrm{~h}$ and reinforced with carbon fibers. As a result, increasing heat treatment temperature decreased the screw withdrawal resistance of test samples. A study by Baltaci (2010) investigated the effects of heat treatment on screw withdrawal resistance of several wood species. He applied heat treatment to Scots pine, Oriental beech, Uludağ fir, and Carolina poplar at $120,160,200{ }^{\circ} \mathrm{C}$ for 2 to 6 h. The highest screw withdrawal resistance was found in oriental beech, while the lowest resistance was found in Uludağ fir. Kariz et al. (2013) reported that heat treatment affected the screws withdrawal capacity of wood because of various factors, one of which was the decrease in density that resulted from high heat treatment temperature. The heat treatment resulted in a decrease in density, and this reduction in density became even more pronounced as the temperature of the heat treatment increased. Therefore, a relationship was observed between the decrease in density and the decrease in screw withdrawal resistance (Aytin et al. 2015).

\section{CONCLUSIONS}

4. ZAKLJUČAK

According to the results, the screw withdrawal resistance decreased with the increasing heat treatment temperature. In terms of the cross sectional direction, the lowest screw withdrawal resistance was found in transverse surface. In terms of wood species, the highest screw withdrawal resistance was found in hornbeam (Carpinus betulus L.), while the lowest resistance value was found in black pine (Pinus nigra Arnold). Screw withdrawal resistance was most affected by heat treatment when hornbeam (Carpinus betulus L.) was used. Screw-withdrawal resistance in heat-treated wood decreased with increasing temperature. Thus, it can be suggested that appropriate wood species should be selected for applications where heattreated wood are to be used, and heat treatment should be carried out at appropriate temperatures. 


\section{REFERENCES}

\section{LITERATURA}

1. Akyildiz, M. H.; Malkoçoğlu, A., 2001: Wood screw withdrawal resistance of some important tree species growing in eastern blacksea region. Artvin Coruh University. Journal of Forestry Faculty, 1 (2): 54-60.

2. Akyildiz, M. H.; Ates, S.; Ozdemir, H., 2009: Technological and chemical properties of heat treated Anatolian black pine wood. African Journal of Biotechnology, 8 (11): 2565-2572.

3. Alén, R.; Kotilainen, R.; Zaman, A., 2002: Thermochemical behavior of Norway spruce (Picea abies) at $180-$ $225^{\circ} \mathrm{C}$. Wood Science and Technology, 36 (2): 163-171. http://dx.doi.org/10.1007/s00226-001-0133-1.

4. ASTM-D 1761 2000: Standard methods of testing mechanical fastener in wood, nail, staple or screw withdrawal test. ASTM International, West Conshohocken, PA.

5. Aytekin, A., 2008: Determination of screw and nail withdrawal resistance of some important wood species. International Journal of Molecular Sciences, 9 (4): 626637. http://dx.doi.org/10.3390/ijms9040626.

6. Ayan, S.; Ciritcioğlu, H. H., 2012: Determination of heat treatment effect on some mechanical properties and screw withdrawal strength of laminated wood panels. Journal of Advanced Technology Sciences, 1 (1): 35-46.

7. Aytin, A.; Korkut, S.; As, N.; Unsal, O.; Gunduz, G., 2015: Effect of heat treatment of wild cherry wood on abrasion resistance and withdrawal capacity of screws. Drvna industrija, 66 (4): 297-303. http://dx.doi.org/10.5552/drind.2015.1440.

8. Baeza, J.; Freer, J., 2001: Chemical characterization of wood and its components. Edited by Hon, D. N. S.; Shiraishi, N. Wood and Cellulosic Chemistry, Second Edition, Revised and Expanded, Marcel Dekker Inc. New York - Basel.

9. Bal, B. C.; Gundes, Z.; Akcakaya, E., 2015: Screw withdrawal strength of plywood produced from poplar, bee$\mathrm{ch}$ and eucalyptus veneer, KSU. Journal of Engineering Sciences, 18 (2): 77-83.

10. Baltac1, S., 2010: Effects of heat treatment on nail and screw withdrawal resistance of some woods. Kastamonu University, master's thesis, $125 \mathrm{~s}$. Kastamonu, Turkey.

11. Bekhta, P.; Niemz, P., 2003: Effect of high temperature on the change in color, dimensional stability and mechanical properties of spruce wood. Holzforschung, 57 (5): 539-546. http://dx.doi.org/10.1515/HF.2003.080.

12. Bhuiyan, T. R.; Hirai, N., 2005: Study of crystalline behavior of heat-treated wood cellulose during treatments in water. Journal of Wood Science, 51 (1): 42-47. http://dx.doi.org/10.1007/s10086-003-0615-x.

13. Boonstra, M. J., 2008: A two-stage thermal modification of wood. Ph.D. dissertation in cosupervision Ghent University and Université Henry Poincaré - Nancy 1, 297 p.

14. Boonstra, M. J.; Tjeerdsma, B., 2006: Chemical analysis of heat-treated softwoods. Holz als Roh- und Werkstoff, 64 (3): 204-211. http://dx.doi.org/10.1007/s00107-005-0078-4.

15. Celebi, G.; Kilic, M., 2006: Nail and screw withdrawal strength of laminated veneer lumber made up hardwood and softwood layers. Construction and Building Materials, 21 (4): 894-900.

http://dx.doi.org/10.1016/j.conbuildmat.2005.12.015.

16. Esteves, B. M.; Domingos, I. J.; Pereira, H. M., 2008: Pine wood modification by heat treatment in air. BioResources, 3 (1): 142-154.

17. Esteves, B. M.; Pereira. H. M., 2009: Wood modification by heat treatment: A review. BioResources, 4: 370-404.
18. Faherty, K. F.; Williamson, T. G., 1998: Wood engineering and construction handbook. McGraw-Hill Handbooks, New York, USA.

19. Fengel, D.; Wegener, G., 1989: Wood: chemistry, ultrastructure, reactions. Walter de Gruyter, Berlin and New York.

20. Gunduz, G.; Korkut, S.; Aydemir, D.; Bekar, I., 2009: The density, compression strength and surface hardness of heat treated hornbeam (Carpinus betulus L.) wood. Maderas. Ciencia y tecnología, 11 (1): 61-70. http://dx.doi.org/10.4067/S0718-221X2009000100005.

21. Gašparík, M.; Barcík, Š.; Boruvka, V.; Holeček, T., 2015: Impact of thermal modification of spruce wood on screw direct withdrawal load resistance. BioResources, 10 (1): 1790-1802.

22. Hill, C. A. S., 2006: Wood modification, chemical, thermal and other processes. John Wiley\&Sons Ltd. England.

23. Kariz, M.; Kuzman, M. K.; Sernek, M., 2013: The effect of heat treatment on the withdrawal capacity of screws in spruce wood. BioResources, 8 (3): 4340-4348. http://dx.doi.org/10.15376/biores.8.3.4340-4348.

24. Kocaefe, D.; Shi, J. L.; Yang, D-Q.; Bouazara, M., 2008: Mechanical properties, dimensional stability, and mold resistance of heat-treated jack pine and aspen. Forest Products Journal, 58 (6): 88-93.

25. Koch, P., 1972: Utilization of the southern pines. U. S. Department of Agriculture, Forest Service, Volume-II (Processing), Agriculture Handbook No. 420, Washington.

26. Korkut, D. S.; Guller, B., 2008: The effects of heat treatment on physical properties and surface roughness of red-bud maple (Acer trautvetteri Medw.) wood. BioResource Technology, 99 (8): 2846-2851.

27. Korkut, S., 2008: The effects of heat treatment on some technological properties in Uludağ fir (Abies bornmuellerinana Mattf.) wood. Building and Environment, 43 (4): 422-428. http://dx.doi.org/10.1016/j.buildenv.2007.01.004.

28. Korkut, S.; Bektaş, I., 2008: The effects of heat treatment on physical properties of Uludağ fir (Abies bornmuellerinana Mattf.) and Scots pine (Pinus sylvestris L.) wood. Forest Products Journal, 58 (3): 95-99.

29. Malek, B. M.; Kookande, M. G.; Taghiyari, H. R.; Mirshokraie, S. A., 2013: Effects of silver nanoparticles and fungal degradation on density and chemical composition of heat-treated poplar wood (Populous euroamerica). European Journal of Wood and Wood Products, 71 (4): 491-495. http://dx.doi.org/10.1007/s00107-013-0708-1.

30. Militz, H., 2002: Thermal treament of wood, European processes and their backround. International Research Group on Wood Protection, No: IRG/WP 02-40241.

31. Ozcifci, A.; Altun, S.; Yapici, F., 2009: Effects of heat treatment on technological properties of wood. $5^{\text {th }}$ International Advanced Technologies Symposium, Karabük, Turkey.

32. Perçin, O., 2015: Determination of screw withdrawal strength of heat-treated and reinforced laminated veneer lumber. BioResources, 11 (1): 1729-1740.

33. Poncsák, S.; Kocaefe, D.; Bouazara, M.; Pichette, A., 2006: Effect of high temperature treatment on the mechanical properties of birch (Betula papyrifera). Wood Science and Technology, 40 (8): 647-663. http://dx.doi.org/10.1007/s00226-006-0082-9.

34. Viitanen, H.; Jämsä, S.; Paajanen, L.; Nurmi, A.; Viitaniemi, P., 1994: The effect of heat treatment on the properties of spruce, A preliminary report. International Research Group on Wood Preservation, Document No. IRG/WP 94-40032. 
35. Viitaniemi, P., 2000: New properties for thermally-treated wood. Industrial Horizons, March, 9 (2000).

36. Wang, J.; Cooper, P., 2005: Effect of oil type, temperature and time on moisture properties of hot oil-treated wood. Holz Roh Werkst, 63 (6): 417-422. http://dx.doi. org/10.1007/s00107-005-0033-4

37. Yildiz, S.; Gezer, E. D.; Yildiz, U. C., 2006: Mechanical and chemical behavior of spruce wood modified by heat. Building and Environment, 41 (12): 1762-1766. http:// dx.doi.org/10.1016/j.buildenv.2005.07.017.

38. Yildiz, S., 2002: Physical, mechanical, technological and chemical properties of beech and spruce wood treated by heating, Ph.D. dissertation. Karadeniz Technical University, Trabzon, Turkey, 200 p.
39. Yildiz, S.; Yildiz, U. C.; Tomak, E. D., 2011: The effects of natural weathering on the properties of heat-treated Alder wood. BioResources, 6 (3): 2504-2521.

\section{Corresponding address:}

Assist. Prof. OSMAN PERÇİN, Ph. D.

Necmettin Erbakan University

Faculty of Fine Arts

Department of Interior Architecture and

Environmental Design

42100, Konya, TURKEY

e-mail: opercin@konya.edu.tr 